\title{
Error Analysis Of Translated Text Made By Maritime Students (in Maritime Context)
}

\author{
Guritno Aditya Warman \\ Program Studi Pendidikan Bahasa Inggris, Fakultas Keguruan dan Ilmu Pendidikan \\ Universitas Widya Gama Mahakam, Indonesia \\ Jl. KH. Wahid Hasyim No. 28 RT.007 Kota Samarinda, Provinsi Kalimantan Timur \\ guritno.aditya.warman.part.2@gmail.com
}

\begin{abstract}
:
Despite its importance, translation is just newly concerned for studies. Maritime students learning Maritime English are often faced with translation activity, especially as a way to introduce new field-specific terms in the learning process. The complex nature of the field has become a challenge to the beginner learners involved in the activity related to the field. The purpose of the study is to investigate the types of error that students often make when translating maritime texts. The participants of the study were 5 maritime students at first year involving in the subject of Maritime English. Instrument utilized in the study was a checklist of translation errors adapted from the theory of Nord (1997). The results indicated that most of translation errors made were related to linguistics translation errors. The conclusion drawn was that the students faced a challenge concerning the lack of English vocabulary, both General English vocabulary and Maritime English terms.
\end{abstract}

Keywords: Translation, Maritime English, English for Specific Purposes

\section{Introduction}

Translation is one important aspect in English education, especially in a form of class activity as a part of Grammar-Translation Method. [16] stated that Grammar-Translation Method has been used in education for a long time. This teaching method can be used to introduce new vocabulary, which is very useful especially in Maritime English as a part of English for Specific Purposes, where introduction to field-specific terms has become a vital aspect. However, [24] concerned that translation in a specific field requires expertise and adequate skill in the corresponding field terminology. This problem will present challenge to beginner learners with lack of background knowledge required in the activity.

Various studies have been conducted by different researchers related to translation. [25] investigated translation errors faced by the students in English Department of a University located in Thailand. The participants were 26 students of Kasetsart University taking English Major at the third year. Content analysis and interviews were conducted to collect the data. The result was that most of the participants faced the syntactic errors. The participants also faced semantic and other problems of translation besides syntactic errors.

On the other hand, [27] observed the English teaching materials which have been translated into other languages to investigate the problems in translation, conducted in University of Kebangsaan Malaysia. The subject of the study was the course content of the current syllabus. The design of the study was content analysis with qualitative approach. The result revealed eight types of translation problems including: Cultural difference, level of language formality, lexical choice, lexical generalization, gender influence, fixed expressions, and foreign adaptation.

Moreover, [26] conducted a research involving beginner English Translators in Iran to find out their problems in translation. The participants were 100 Iranian graduates and undergraduates who were finding jobs as translators. The object of the research was translation texts done by the translators. The translation problems which emerged in the research are categorized into three categories including: lexical problems, cultural problems, and stylistic problems.

Additionally, [14] conducted a case study with a number of 75 participants of English linguistics students in Russia. The research took place in the Tomsk State University. The objective of the research was to learn about the students' problems in translating American 
context-specific texts. The result of the study was that the problems of translation were mainly caused by the lack of lexical knowledge, background information, metaphoric competence, and listening comprehension.

Furthermore, [13] investigated the problems of translation in genre-specific text faced by students in Hungary. The research involved 10 full-time students taking specialized European United Translation Course, and took place in Eszterházy Károly College, Hungary, at English Department in Academic Year of 2009-2010. The participants were at the third year of their study and took an English BA Program. The result of the research was that the students faced the problems of translation in categories including: lexical, syntactic, and textual patterns.

This research also investigated the problem of translation. However, this research focused on investigation in area of Maritime English as English for Specific Purposes. Maritime students were chosen to be the participants of the study. Content analysis was chosen as the research design, using qualitative approach for analysis purpose. There are many theories regarding the errors of translation. However, researcher focused on the theory of [20] to identify errors of translation made by the participants of the research. A checklist of translation errors was made to identify errors made by the participants. This checklist of translation errors was made based on the theory by [20]. The research was conducted to answer a question, "What types of error do students often make when translating maritime texts?"

\section{Methodology}

\section{a. Research Design}

The researcher determined content analysis as the design for the research. [15] defined content analysis as a method of study involving a conclusion-drawing from texts regarding their contexts. In this research, the researcher analyzed errors made by students in their translation text. The conclusion which was drawn was related to the types of translation errors. Content analysis was considered as the appropriate design for the study due to the involvement of text in the process, and the context which would require the participants to make a good analysis in their translation process in order to make a good translation. The research used qualitative approach to interpret the results of the research and in order to draw conclusion.

\section{b. Participants and Procedure}

The participants were 5 first-year students of SMK Negeri Pelayaran Kalimantan Samarinda. The researcher conducted a translation test to be taken by the participants. The participants were asked to translate a text entitled "The Deck Department" adopted from textbook entitled "English for Maritime Studies". After the test was completed, the researcher then analyzed and collected all errors made by the participants. These errors then categorized according to the types of errors based on the theory from [20].

\section{c. Data Collection and Analysis}

To investigate the types of translation error made by participants, the researcher referred to the theory of translation errors by [20]. The translation errors were categorized as four different types including Pragmatic Translation Errors, Linguistics Translation Errors, Textual Translation Errors, and Cultural Translation Errors. The researcher also referred to a theory from [23], who provided further description to the theory given by [20]. Based on the theory, the researcher constructed a translation error checklist used to categorize the translation errors made by the participants.. 


\section{Findings and Discussion Findings}

The research was conducted to answer a question, "What types of error do students often make when translating maritime texts?" The table below summarizes the results of the study to answer the research question.

Table 1. Types and Numbers of error students did when translating maritime texts

\begin{tabular}{|c|c|c|c|}
\hline No & Categories & Sub Categories/Indicators & Number of Errors Found \\
\hline \multirow[t]{2}{*}{1} & $\begin{array}{c}\text { Pragmatic Translation } \\
\text { Errors }\end{array}$ & $\begin{array}{l}\text { Motivation of target text or source } \\
\text { text }\end{array}$ & 7 \\
\hline & & The text function & 1 \\
\hline \multirow[t]{2}{*}{2} & Linguistics Translation & Lexical Problem & 19 \\
\hline & & Terminological Problem & 12 \\
\hline \multirow[t]{5}{*}{3} & Textual Translation & Omission of Preposition & 1 \\
\hline & & Inappropriate use of Preposition & 1 \\
\hline & & Inappropriate use of Punctuation & 1 \\
\hline & & $\begin{array}{l}\text { Problems of Coherence and } \\
\text { Cohesion in Target Text }\end{array}$ & 1 \\
\hline & & TOTAL ERRORS & 43 \\
\hline
\end{tabular}

\section{Discussion}

According to the result of the study, most of the problems faced by the participants were related to linguistics errors. These problems indicated the lack of vocabulary skills, related to general and field-specific terms.

The main problems found in this research are similar to the finding of previous research which was conducted by [25] where it was concluded that the main problems were mainly related to syntactic and semantic errors, considering that these two categories are closely related to linguistics. Wongranu used a classification of translation errors by Pojprasat, whereas this research referred to theory of [20]. Although both researches found the final results related to linguistics, there is a main difference between the results of these two researches. The research by [25] actually found that the biggest problem face by participants was mainly related to syntactic, a branch of linguistics focusing on the structure of the text. In the classification by [20] which was used in this research, errors related to text is classified as a distinct category, instead of a sub-category under linguistics. Moreover, most of the problems found in this research are related to vocabulary, instead of the structure of the text.

Additionaly, Yousoufi (2014), Klassen et al. (2015), and Károly (2012) found similar results to the finding of this research, despite differences in the use of theories as guidance in the process of the researches. The researches confirmed that linguistics errors, mainly the problems related to vocabulary, were the major difficulties faced by translators. 
[24] stated that translation in a specific field of study requires an adequate skill in understanding terminologies related to the corresponding field. On the other hand, the participants of this study were the beginner students which were newly exposed to specific vocabulary related to maritime industry. The low vocabulary skills led the participants to the problem of linguistics translation errors.

However, [19] stated that translation is a form of teaching method which can be used as a means of learning a new language. Thus, the method can be utilized to introduce new terminologies to the students. Furthermore, [16] also stated that Grammar-Translation method, in which the activity of translation is involved, has been used for a long time in education.

The main problems of linguistics translation errors were mainly caused by low skill in vocabulary mastery. This is due to the fact that students were new to the field of study. Despite the problems of vocabulary found in the activity of translation, the method of teaching involving translation activities is actually a way in introducing new terminologies to the students.

As stated by [1] translation is a newly concerned field of study. The researcher expects that the result of the study will give contribution to the corresponding study. The research also concerns about the field of Maritime English which was not covered in previous studies that the researcher referred to. According to [24] a good proficiency in field-specific terminology is required in translation activities involving English for Specific Purposes. The research revealed that the participants faced the problems related to specific terms related to Maritime English, confirming the theory from Chesterman (2012). However, the linguistics problems faced by the participants in the research were mostly related to misunderstanding the general phrases, instead of the specific terms. On the other hand, the problems related to specific terms in the research were the second biggest problems faced by the participants. This finding is an indication that there is actually a relationship between the capabilities in general vocabulary and the proficiency in specific-field terms.

\section{Conclusion}

There are a total of 43 translation errors found in the research involving 5 participants of maritime students. Most of the translation errors fell into the category of linguistic errors with a total of 31 translation errors. On the other hand, the participants also made 8 pragmatic translation errors and 4 textual translation errors. The category of cultural translation errors was also included in the analysis process. However, no errors were found related to cultural translation errors.

The result of the research showed that the biggest problem that was faced by the participant was related to linguistic translation errors. The translation errors found in the research mostly indicated that the students faced big challenges in recognizing vocabulary appeared in the source text. Not only did the students face the problem in recognizing technical terms, but also general vocabulary which involved phrases. Some participants mistreated phrases as separated words, which caused meaning shifts. On the other hand, the problem in recognizing technical terms might be the indication that the students were still unfamiliar with the field of the subject and lack exposure to the field-specific vocabulary. 


\section{References}

[1] S. Basnett, "Translation", New York: Routledge, 2014.

[2] H. Basturkmen, "Developing Courses in English for Specific Purposes", Basingstoke: Palgrave Macmillan, 2010.

[3] T.N. Blakey, "English for Maritime Studies", Hertfordshire: Prentice Hall International (UK) Ltd, 1987.

[4] H.D. Brown, "Principles of Language Learning and Teaching", New York: Pearson Education, Inc, 2007.

[5] J. Byrne, "Technical Translation: Usability Strategies for Translating Technical Documentation”, Dordrecht: Springer, 2006.

[6] A. Coxhead, "Vocabulary and English for Specific Purposes Research: Quantitative and Qualitative Perspectives", New York: Routledge, 2018.

[7] J.W. Creswell, "Educational Research: Planning, Conducting and Evaluating Quantitative and Qualitative Research", Boston: Pearson Education, Inc, 2012.

[8] N.K. Denzin, "The Research Act:A Theoretical Introduction to Sociological Methods", New York: McGraw-Hill Book Company, 1970.

[9] H. Ghazala, "Translation as problems and Solutions: A Textbook for Universities Students and Trainee Translators", Beirut: Dar El Ilm Lilmalayin, 2008.

[10] International Maritime Organization, "IMO Standard Marine Communication Phrases (SMCP)", Rijeka: Rijeka College of Maritime Studies, 2000.

[11] International Maritime Organization, "International Convention on Standards of Training, Certification and Watchkeeping for Seafarers (STCW)", London: International Maritime Organization, 2005.

[12] P. John, et al, "Profiling Maritime Communication by Non-native Speakers: A Quantitative Comparison between the Baseline and Standard Marine Communication Phraseology", English for Specific Purposes. Vol. 47. Pp. 1-14, 2017.

[13] A. Károly, "Translation Competence and Translation Performance: Lexical, Syntactic and Textual Patterns in Student Translations of Specialized EU Genre", English for Specific Purposes, Vol. 31, Pp. 36-46, 2012.

[14] E.V. Klassen, et.al, "Lost in Translation: Case Study of Interpreting American SBUs by Russian EFL Learners Majoring in Linguistics", Procedia Social and Behavioral Sciences, Vol. 200, Pp. 243-247, 2015.

[15] K. Krippendorff, "Content Analysis: An Introduction to Its Methodology", Thousand Oaks: SAGE Publications, Inc, 2004.

[16] D. Larsen-Freeman, "Techniques and Principles in Language Teaching", Oxford: Oxford University Press, 2003.

[17] M.B. Miles, et al., "Qualitative Data Analysis: A Methods Sourcebook", Thousand Oaks: SAGE Publications, Inc, 2014.

[18] L. Molina, and A.H. Albir, "Translation Techniques Revisited: A Dynamic and Functionalist Approach", META. Vol. XLVII, No.4, Pp. 498-512, 2002.

[19] J. Munday, "Introducing Translation Studies: Theories and Applications", New York: Routledge, 2010.

[20] C. Nord, "Translating as a Purposeful Activity: Functionalist Approaches Explained", Manchester: St. Jerome Publishing, 1997.

[21] Oxford University Press, "Oxford Advanced Learner's Dictionary", (app edition) (Version 1.0.12.0) [Mobile application software]. [Online]. Available: https://play.google.com, 2016.

[22] J.C. Richards, and T.S. Rodgers, "Approaches and Methods in Language Teaching", Cambridge: Cambridge University Press, 2001. 
[23] L.R Stiegelbauer, et al., "Translation Problems and Difficulties in Applied Translation Processes", Studii de ştiinţă şi cultură, 12(3).Pp. 51-58, 2016.

[24] J. Williams, and A. Chesterman, "The Map: A Beginner's Guide to Doing Research in Translation Studies", Manchester: St. Jerome Publishing, 2002.

[25] P. Wongranu, "Errors in Translation made by English Major Students: A Study on Types and Causes", Kasetsart Journal of Social Sciences, 38. Pp. 117-122, 2017.

[26] N. Yousofi, "Describing the Errors in the Translations of Iranian Novice English Translators", Procedia Social and Behavioral Sciences, Vol. 98. Pp. 1952-1958, 2014.

[27] N.Md. Yusof, et.al., "The Translation of Foreign Language Teaching and Learning Materials for Universiti Kebangsaan Malaysia", Website: Preliminary Problems and Chalenge, 2010. 